\title{
Medical Nutrition Therapy: A Key to Diabetes Management and Prevention
}

\author{
Sara F. Morris, MAT, MPH, RD, and Judith Wylie-Rosett, EdD, RD
}

$\mathrm{T}$ The link between diabetes and diet has been well documented, as has the importance of diet in conjunction with medical interventions for diabetes. Patients often look to their primary care physicians for advice about general diabetes care, including diet, but survey studies have revealed that doctors feel uncomfortable advising patients on the sensitive issues of weight loss and diet. ${ }^{1}$

Research is increasingly demonstrating that medical nutrition therapy (MNT), administered by a registered dietitian (RD) or nutrition professional, is a key component of diabetes management and a complement to treatment of diabetes by physicians.

The American Diabetes Association (ADA) 2009 clinical practice recommendations state that "individuals who have pre-diabetes or diabetes should receive individualized MNT as needed to achieve treatment goals, preferably provided by a registered dietitian familiar with the components of diabetes MNT.," Furthermore, the ADA's position statement titled "Nutrition Recommendations and Interventions for Diabetes" emphasizes the importance of MNT in preventing diabetes, managing existing diabetes, and preventing and slowing the onset of diabetes-related complications. ${ }^{3}$ The integration of MNT into diabetes care has the potential to improve patients' diabetes management and to lessen the burden on physicians to provide nutrition information.

\section{Defining MNT}

MNT is defined as "nutritional diagnostic, therapy, and counseling services for the purpose of disease management, which are furnished by a registered dietitian or nutrition professional." The American Dietetic Association, the professional organization of RDs, defines the nutrition counseling component of MNT as "a supportive process to set priorities, establish goals, and create individualized action plans which acknowledge and foster responsibility for self-care."'

In general, MNT consists of multiple, one-on-one sessions between an RD and a patient, in which the RD performs the nutrition assessment, diagnosis, counseling, and other therapy services according to the American Dietetic Association's "MNT Evidence-Based Guide for Practice/Nutrition Protocol" or according to the best available current evidence in the nutrition

\section{IN BRIEF}

Because of the direct correlation between diet and diabetes management, medical nutrition therapy (MNT) provided by a registered dietitian is a key complement to traditional medical interventions in diabetes treatment. This article describes MNT, summarizes evidence for the effectiveness of MNT in preventing and treating diabetes, and provides physicians with information about how to refer patients for MNT. community. ${ }^{5}$ After an $\mathrm{RD}$ receives a referral from a physician, the framework of counseling is standardized and documented as part of the American Dietetic Association's Nutrition Care Process (nutrition assessment, nutrition diagnosis, nutrition intervention, nutrition monitoring, and evaluation). ${ }^{6}$

The components of MNT provided by an RD, according to the Nutrition Care Process for any nutrition-related disease (not just diabetes), are outlined in Table $1 .{ }^{7}$ Initially, the dietitian performs a nutrition assessment of the patient's dietary patterns. This assessment, in conjunction with information about laboratory testing, medications, and any other conditions that the RD would have received with the physician referral, allows the RD to evaluate such factors as the patient's macronutrient needs versus intake, the consistency of meals, the amount and consistency of carbohydrate intake, and the general quality of the patient's diet. The RD can then issue a coded, standardized nutrition diagnosis and tailor future individual counseling to help the patient meet goals related to the diagnosis and nutrition needs.

As an example, after reviewing a patient's physician referral information and dietary patterns, an RD might issue the following diagnostic statement: "Inconsistent carbohydrate intake related to inadequate meal planning as evidenced by meals and snacks containing a range from 
Table 1. MNT Provided by RDs

\begin{tabular}{|c|c|}
\hline Application of Nutrition Care Process & MNT Provided by RD (for individual) \\
\hline Nutrition screen/referral & $\begin{array}{l}\text { The physician provider sends RD written referral for MNT for diabetes. The } \\
\text { referral includes information regarding current laboratory test results, medica- } \\
\text { tions, and other medical diagnoses. }\end{array}$ \\
\hline Nutrition assessment & $\begin{array}{l}\text { The RD performs a comprehensive nutrition assessment utilizing the Diabetes } \\
\text { Type } 1 \text { and } 2 \text { Evidenced-Based Nutrition Practice Guideline for Adults and } \\
\text { Toolkit, as well as the best available current knowledge and evidence, client } \\
\text { data, medical record data, and other resources. }\end{array}$ \\
\hline Nutrition diagnosis & $\begin{array}{l}\text { After analyzing assessment data, the RD makes initial nutrition diagnosis(es); } \\
\text { for example, inconsistent carbohydrate intake (diagnosis code NI-5.8.4), in- } \\
\text { consistent timing of carbohydrate intake throughout the day, day to day, or a } \\
\text { pattern of carbohydrate intake that is not consistent with recommended pattern } \\
\text { based on physiological or medication needs. }\end{array}$ \\
\hline Nutrition intervention & $\begin{array}{l}\text { The RD provides counseling and, with the client, determines interventions using } \\
\text { the cognitive behavioral model, including problem solving, motivational inter- } \\
\text { viewing, goal setting, and self-monitoring. }\end{array}$ \\
\hline \multirow[t]{2}{*}{ Nutrition monitoring and evaluation } & $\begin{array}{l}\text { The RD monitors A1C, microalbuminuria, BMI, serum lipid levels, goals for } \\
\text { food plan/intake, activity, and other behavior changes. }\end{array}$ \\
\hline & $\begin{array}{l}\text { The RD implements changes to MNT (e.g., patient education goals, nutrition } \\
\text { intervention, and counseling) in future visits based on outcomes and assess- } \\
\text { ments at each visit. }\end{array}$ \\
\hline $\begin{array}{l}\text { Nutrition documentation (supports all } \\
\text { steps of the Nutrition Care Process) }\end{array}$ & $\begin{array}{l}\text { The RD documents MNT initial assessment, nutrition diagnosis(es), and } \\
\text { intervention(s); shares with referring physician; and keeps a copy on file. }\end{array}$ \\
\hline Outcome management systems & $\begin{array}{l}\text { Based on RD analysis, critical thinking, and review of data from the patient's } \\
\text { medical history and other health care professionals, the RD aggregates individ- } \\
\text { ual and population outcomes data; analyzes and shares with quality improve- } \\
\text { ment department/group as indicated; and implements improvements to MNT } \\
\text { services based on results. }\end{array}$ \\
\hline
\end{tabular}

0 to $150 \mathrm{~g}$ of carbohydrates on a daily basis." The nutrition intervention for this diagnostic statement might consist of the RD teaching the patient to plan meals and carbohydrate intake using the diabetes plate model or the carbohydrate exchange methods, helping the patient set goals related to consistent intake, and then using motivational interviewing or problem solving to address any barriers the patient has to meeting nutritional goals. ${ }^{8,9}$

As part of nutrition monitoring and evaluation, the RD monitors biochemical factors such as A1C and serum lipid levels, as well as lifestyle factors such as dietary intake. Depending on how many sessions the RD has with the patient, these factors are used to evaluate the effectiveness of interventions in meeting goals. Diagnoses and interventions might then be revised based on nutrition-related outcomes. Therefore, MNT for nutritionrelated disorders such as diabetes is not necessarily a linear process. Counseling in MNT is individualized and tailored to a patient's clinical and lifestyle needs.
MNT is not synonymous with diabetes self-management training (DSMT). DSMT is an education and training program that helps patients manage their diabetes, whereas MNT consists of more individualized diagnosis, therapy, and counseling related to nutrition. ${ }^{7}$

According to the American Dietetic Association's 2009 White Paper on Nutrition Services that distinguishes between the delivery of DSMT and MNT services, the DSMT curriculum that is accredited by Medicare consists of 1 hour of individualized assessment and 
9 hours of group classes. ${ }^{7}$ One of the content areas outlined in the DSMT curriculum is "incorporating nutritional management into lifestyle," but others are less nutrition related, such as "using medications safely and for maximum therapeutic effectiveness."

MNT for patients with diabetes is administered in several sessions with an RD, who provides "more intensive nutrition counseling and a therapy regimen that relies heavily on follow-up and feedback to assist patients with changing their behavior(s) over time." Furthermore, although MNT for diabetes patients can be administered only by a licensed/certified RD or nutrition professional, DSMT can be administered by a registered nurse, dietitian, or pharmacist. ${ }^{\text {? }}$

Sometimes it may be most helpful for patients to receive DSMT first, followed by MNT. Other patients may receive DSMT and MNT simultaneously. Professional organizations such as the ADA, the American Dietetic Association, and the Centers for Medicare and\& Medicaid Services recognize both the distinctions between DSMT and MNT and the possibility that the two programs can complement each other.

\section{Effectiveness of MNT in Diabetes Treatment and Prevention: A Summary of Current Literature}

Research has shown MNT to be effective for the treatment of both type 1 and type 2 diabetes. The American Dietetic Association reviewed 18 studies that involved the provision of MNT by an RD as part of treatment for either type 1 or type 2 diabetes. Of these, all 8 of the randomized controlled trials reviewed demonstrated a positive effect of MNT in diabetes management, measured by improvement in $\mathrm{A} 1 \mathrm{C}$ levels. ${ }^{10}$ Based

Table 2. Summary of Evidence for Nutrition Therapy in Diabetes ${ }^{11-26}$

\begin{tabular}{|c|c|c|c|}
\hline References & Study Length & Number of Subjects & Outcome \\
\hline \multicolumn{4}{|c|}{ Randomized, controlled trials } \\
\hline \multicolumn{4}{|l|}{ MNT only } \\
\hline $\begin{array}{l}\text { UKPDS Study } \\
\text { Group, } 1990^{12}\end{array}$ & 3 months & $\begin{array}{l}3,042 \text { patients with newly } \\
\text { diagnosed type } 2 \text { diabetes }\end{array}$ & $\begin{array}{l}\text { In } 2,595 \text { patients who received intensive nutrition } \\
\text { therapy ( } 447 \text { were primary diet failures), A1C decreased } \\
1.9 \% \text { (from } 8.9 \text { to } 7 \% \text { ) during the } 3 \text { months before study } \\
\text { randomization }\end{array}$ \\
\hline Franz et al., $1995^{13}$ & 6 months & $\begin{array}{l}179 \text { people with type } 2 \\
\text { diabetes; } 62 \text { in compari- } \\
\text { son group; duration of } \\
\text { diabetes: } 4 \text { years }\end{array}$ & $\begin{array}{l}\text { A1C at } 6 \text { months decreased } 0.9 \% \text { (from } 8.3 \text { to } 7.4 \% \text { ) with } \\
\text { nutrition practice guidelines care; A1C decreased } 0.7 \% \\
\text { (from } 8.3 \text { to } 7.6 \% \text { ) with basic nutrition care; A1C was } \\
\text { unchanged in the comparison group with no nutrition } \\
\text { intervention (from } 8.2 \text { to } 8.4 \% \text { ) }\end{array}$ \\
\hline $\begin{array}{l}\text { Kulkarni et al., } \\
1998^{14}\end{array}$ & 6 months & $\begin{array}{l}54 \text { patients with newly di- } \\
\text { agnosed type } 1 \text { diabetes }\end{array}$ & $\begin{array}{l}\text { A1C at } 3 \text { months decreased } 1.0 \% \text { (from } 9.2 \text { to } 8.2 \% \text { ) } \\
\text { with nutrition practice guideline care and } 0.3 \% \text { (from } \\
9.5 \text { to } 9.2 \% \text { ) in usual nutrition care group }\end{array}$ \\
\hline \multicolumn{4}{|c|}{ MNT in combination with DSMT } \\
\hline $\begin{array}{l}\text { Glasgow et al., } \\
1992^{15}\end{array}$ & 6 months & $\begin{array}{l}162 \text { type } 2 \text { diabetic pa- } \\
\text { tients }>60 \text { years of age }\end{array}$ & $\begin{array}{l}\text { A1C decreased from } 7.4 \text { to } 6.4 \% \text { in the control-interven- } \\
\text { tion crossover group, whereas the intervention-control } \\
\text { crossover group had a rebound effect; the intervention } \\
\text { group had a multidisciplinary team with an RD who } \\
\text { provided MNT }\end{array}$ \\
\hline Sadur et al., $1999^{16}$ & 6 months & $\begin{array}{l}185 \text { adult patients with } \\
\text { diabetes }\end{array}$ & $\begin{array}{l}97 \text { patients received multidisciplinary care, and } 88 \\
\text { patients received usual care by primary care MD; A1C } \\
\text { decreased } 1.3 \% \text { in the multidisciplinary care group } \\
\text { compared with } 0.2 \% \text { in the usual care group; interven- } \\
\text { tion group had a multidisciplinary team with an RD } \\
\text { who provided MNT }\end{array}$ \\
\hline
\end{tabular}


Table 2. Summary of Evidence for Nutrition Therapy in Diabetes, ${ }^{11-26}$ continued from page 14

\begin{tabular}{|c|c|c|c|}
\hline References & Study Length & Number of Subjects & Outcome \\
\hline \multicolumn{4}{|c|}{ Observational studies } \\
\hline \multicolumn{4}{|c|}{ Cross-sectional survey } \\
\hline $\begin{array}{l}\text { Delahanty and } \\
\text { Halford, } 1993^{17}\end{array}$ & 9 years & $\begin{array}{l}623 \text { patients with type } 1 \\
\text { diabetes }\end{array}$ & $\begin{array}{l}\text { Patients who reported following their meal plan }>90 \% \\
\text { of the time had an average A1C level } 0.9 \% \text { lower than } \\
\text { subjects who followed their meal plan }<45 \% \text { of the time }\end{array}$ \\
\hline \multicolumn{4}{|l|}{ Expert opinion } \\
\hline $\begin{array}{l}\text { DCCT Research } \\
\text { Group, } 1993^{18}\end{array}$ & & & $\begin{array}{l}\text { The Diabetes Control and Complications Trial } \\
\text { (DCCT) research group recognized the importance of } \\
\text { the role of the RD in educating patients on nutrition } \\
\text { and adherence to achieve A1C goals; the RD was a key } \\
\text { member of the team }\end{array}$ \\
\hline Franz et al., $1994^{19}$ & & & $\begin{array}{l}\text { The DCCT made apparent that RDs and RNs were } \\
\text { extremely important members of the team in co-man- } \\
\text { aging and educating patients }\end{array}$ \\
\hline \multicolumn{4}{|l|}{ Chart audit } \\
\hline $\begin{array}{l}\text { Johnson and } \\
\text { Valera, } 1995^{20}\end{array}$ & 6 months & $\begin{array}{l}19 \text { patients with type } 2 \\
\text { diabetes }\end{array}$ & $\begin{array}{l}\text { At } 6 \text { months, blood glucose levels decreased } 50 \% \text { in } \\
76 \% \text { of patients receiving nutrition therapy by an RD. } \\
\text { Mean total weight reduction was } \sim 5 \mathrm{lb}\end{array}$ \\
\hline $\begin{array}{l}\text { Johnson and } \\
\text { Thomas, } 2001^{21}\end{array}$ & 1 year & 162 adult patients & $\begin{array}{l}\text { MNT intervention decreased A1C levels } 20 \% \text {, bringing } \\
\text { mean levels to }<8 \% \text { compared with subjects without } \\
\text { MNT intervention, who had a } 2 \% \text { decrease in A1C } \\
\text { levels }\end{array}$ \\
\hline \multicolumn{4}{|c|}{ Retrospective chart review } \\
\hline $\begin{array}{l}\text { Christensen et al., } \\
2000^{22}\end{array}$ & 3 months & $\begin{array}{l}102 \text { patients ( } 15 \text { type } 1 \\
\text { and } 85 \text { type } 2 \text { diabetic } \\
\text { patients with duration of } \\
\text { diabetes }>6 \text { months) }\end{array}$ & $\begin{array}{l}\text { A1C levels decreased } 1.6 \% \text { (from } 9.3 \text { to } 7.7 \% \text { ) after refer- } \\
\text { ral to an RD }\end{array}$ \\
\hline \multicolumn{4}{|c|}{ Meta-analyses of trials } \\
\hline $\begin{array}{l}\text { Brown et al., 1996, } \\
1990^{23,24}\end{array}$ & & 89 studies & $\begin{array}{l}\text { Educational intervention and weight loss outcomes; } \\
\text { MNT had a statistically significant positive impact on } \\
\text { weight loss and metabolic control }\end{array}$ \\
\hline $\begin{array}{l}\text { Padgett et al., } \\
1988^{25}\end{array}$ & & 7,451 patients & $\begin{array}{l}\text { Educational and psychosocial interventions in man- } \\
\text { agement of diabetes (including MNT, self-monitoring } \\
\text { of blood glucose, exercise, and relaxation); nutrition } \\
\text { education showed strongest effect }\end{array}$ \\
\hline $\begin{array}{l}\text { Norris et al., } \\
2001^{26}\end{array}$ & & 72 studies & $\begin{array}{l}\text { Positive effects of self-management training on knowl- } \\
\text { edge, frequency, and accuracy of self-monitoring of } \\
\text { blood glucose, self-reported dietary habits, and glyce- } \\
\text { mic control were demonstrated in studies with short } \\
\text { follow-up (<6 months) }\end{array}$ \\
\hline
\end{tabular}


on this review, the American Dietetic Association reports strong support for the effectiveness of MNT provided by RDs in the management of type 1 and type 2 diabetes and suggests that MNT has the greatest potential for impact when diabetes is first diagnosed. ${ }^{10}$

Several studies in which MNT was included in diabetes treatment interventions that successfully affected metabolic and behavioral outcomes are summarized in Table 2, adapted from Pastors et al. ${ }^{11-26}$ The studies varied in design and length (from 3 months to 9 years), and some were conducted before MNT for diabetes was as well defined as it is today. However, all studies listed implemented at least one study group that received individual counseling from an RD, with number of sessions ranging from two total sessions to monthly sessions for 6 months or more. These studies reported improvements in A1C ranging from 0.9 to $1.9 \%$ for groups receiving MNT and generally reported a greater improvement in $\mathrm{A} 1 \mathrm{C}$ when compared to study groups that received less intensive or basic nutrition education. ${ }^{11}$ In general, Pastors et al. summarize that "randomized controlled nutrition therapy outcome studies have documented decreases in $[\mathrm{A} 1 \mathrm{C}]$ of $\sim 1 \%$ in newly diagnosed type 1 diabetes, $2 \%$ in newly diagnosed type 2 diabetes, and $1 \%$ in type 2 diabetes with an average duration of 4 years." 11

MNT has also been shown to be effective in the prevention of type 2 diabetes. Although the onset of type 1 diabetes is not considered to be preventable, the onset of type 2 diabetes can be delayed or prevented with lifestyle modifications, including changes to diet. Based on its review of seven studies that implemented nutrition therapy and 16 studies that implemented intensive lifestyle interventions including nutrition therapy, the American Dietetic Association concluded that MNT is "effective at reducing the incidence of type 2 diabetes." 10

The same review concluded that pharmacotherapy is also effective at reducing incidence of type 2 diabetes, but stated that in all but one of seven studies reviewed, lifestyle interventions were more effective than pharmacotherapy at reducing incidence. ${ }^{10}$ Regarding pharmacotherapy, it should be noted that although the ADA clinical practice recommendations do endorse the use of medications to treat certain complications of diabetes, they also endorse MNT and lifestyle changes as alternatives and complements to pharmacotherapy. ${ }^{2}$

A notable prevention study is the Diabetes Prevention Program, reported in $2002 .{ }^{27}$ In this randomized, controlled trial of 1,079 participants aged $25-84$ years, a $58 \%$ reduction in incidence of diabetes over 3 years was reported in subjects treated with an intensive lifestyle intervention that included MNT.

Based on the results of this prevention intervention, the Look AHEAD (Action for Health in Diabetes) study is currently underway to test the effects of similar lifestyle interventions in the treatment of 5,145 men and women who have already been diagnosed with type 2 diabetes. ${ }^{28}$ Although this trial is planned to extend for 11.5 years, the researchers' recently published 1-year results reported that the intensive lifestyle intervention group lost $8.6 \%$ of initial weight compared to $0.7 \%$ in the control group. ${ }^{28}$ The intensive lifestyle intervention included comprehensive diet counseling from an RD, whereas the control group received basic, or "usual," care for diabetes. The experimental group also had significantly greater decreases in $\mathrm{A} 1 \mathrm{C}$, systolic and diastolic blood pres- sure, and triglyceride levels in the first year, compared to the control group. $^{28}$

The body of evidence pointing to the effectiveness of MNT in treating, and now preventing, adult type 2 diabetes continues to grow. However, research on the effectiveness of MNT for diabetes in children and adolescents is still limited. The Diabetes Control and Complications Trial, reported in 1993, did include subjects aged $13-39$ years. ${ }^{29}$ This randomized, controlled trial showed $34-76 \%$ reductions in complications of type 1 diabetes in the study group, which received both intensive insulin therapy and monthly clinic visits with an RD.

It is only within the past decade that the prevalence of type 2 diabetes among children and adolescents has been recognized, but studies currently underway are demonstrating that the incidence and prevalence of type 2 diabetes are increasing. ${ }^{30,31}$ Therefore, there is a need for research to identify the most effective interventions to address the prevention and treatment of type 2 diabetes in children and adolescents. Even so, based on the existing evidence pertaining to adults with type 2 diabetes, the contribution of MNT to the prevention and treatment of this disease in children is promising.

\section{MNT and Third-Party Coverage}

Although the ADA and the American Dietetic Association are in agreement that patients with pre-diabetes and diagnosed diabetes should be referred for MNT, many primary care physicians are unsure of how to go about making these referrals.

Government Medicare insurance benefits cover Americans $>65$ years of age, some disabled people $<65$ years of age, and people of any age who have end-stage renal disease. ${ }^{32}$ Since 2000, Medicare benefits have covered MNT for people with type 
1 diabetes, type 2 diabetes, gestational diabetes, non-dialysis kidney disease, and post-kidney transplants who are otherwise eligible for Medicare insurance. ${ }^{4}$

Medicare generally serves as the standard for other third-party payers, so many private and state insurance plans also cover MNT for diabetes management. In fact, as of 2009, 46 states and the District of Columbia have legislation in place that requires insurance coverage for diabetes management, although the breadth of coverage offered varies greatly from state to state. ${ }^{33}$

However, although Medicare and other third-party payers cover diabetes screening for patients who have been diagnosed with pre-diabetes, Medicare does not currently cover MNT for patients with pre-diabetes. ${ }^{34}$ The Diabetes Prevention Program study has done much to underscore the effectiveness and cost-effectiveness of lifestyle interventions, including MNT, in preventing or delaying the onset of type 2 diabetes..$^{27,35}$ In this time of insurance reform, it is possible that coverage for MNT for pre-diabetes, considered to be a preventive service, will become more widespread.

It is important to note that Medicare coverage of MNT for people with diabetes requires a physician referral. According to Medicare MNT legislation, patients with a physician referral can receive 3 hours of individual counseling with an RD during the first year of treatment and 2 hours of counseling each year after that. ${ }^{4,5,7}$ Medicare also covers DSMT in addition to MNT without decreasing the benefit of either.?

Patients who are not covered under Medicare insurance should still be referred for MNT because many private insurers will cover MNT for diabetes and other conditions. ${ }^{36}$ To ensure that patients will be eligible to receive MNT through third-party coverage, the American Dietetic Association suggests the following guidelines for physicians: ${ }^{36}$

- Take care to include the diagnosis and diagnosis code for diabetes on the referral form.

- Submit pertinent recent lab results and medication lists with referrals.

- Document patients' need for MNT in their medical charts.

- Encourage patients to make an appointment with an RD at a local hospital, clinic, or private practice office, and assist them in locating an RD if they are unsure how to do so.

- Provide another referral and make appropriate medical record documentation if and when patients need additional hours of MNT.

To assist patients in locating an RD, physicians can access the "Find a Nutrition Professional" section of the American Dietetic Association's Web site, www.eatright.org.

Some nutrition professionals hold the certified diabetes educator (CDE) credential in addition to the $\mathrm{RD}$ credential. CDEs are defined as "health care professionals who have defined roles as diabetes educators, not ... those who may perform some diabetes-related functions as part of or in the course of other usual and customary occupational duties." ${ }^{.37}$ CDEs may be nurses, doctors, dietitians, or other health care providers. Whatever their discipline, they must have 2 full years of professional practice experience, perform 1,000 hours of diabetes self-management education (DSME), and take an accreditation examination to earn the CDE credential.

DSME is synonymous with DSMT. Therefore, the scope of diabetes self-management education provided by CDEs includes not only a nutrition education component, but also education and training in the effects of diabetes- related medicines, self-monitoring of blood glucose, and administering insulin. ${ }^{6,37}$

The difference between DSMT/ DSME and MNT has been explained; the treatments are complementary but not identical in scope. Therefore, although a health care professional who is a CDE may be able to advise patients regarding some aspects of diabetes nutrition, only an RD can provide intensive MNT.

It is arguably ideal to refer patients who need diabetes MNT to RDs who are also CDEs, because these individuals would be experts in the nutrition aspect of diabetes and trained to educate patients in some non-nutrition aspects of diabetes management. However, the professional to whom patients are referred for MNT must, at the minimum, hold the RD credential.

\section{Conclusion}

MNT is an effective and increasingly affordable method to prevent type 2 diabetes and to treat both type 1 and type 2 diabetes. It is endorsed for the treatment of diabetes by the Institute of Medicine, the American Dietetic Association, and the ADA and is covered by Medicare. The provision of MNT by RDs, who are experts in offering individualized nutrition counseling, will improve the quality of counseling offered to patients and alleviate the burden on physicians to provide nutrition education. Primary care physicians should refer patients with symptoms of pre-diabetes and diabetes for MNT services, to be provided by an $\mathrm{RD}$, to ensure the best care for their patients.

\section{REFERENCES}

${ }^{1}$ Gans KM, Ross E, Barner CW, WylieRosett J, McMurray J, Eaton C: REAP and WAVE: new tools to assess/discuss nutrition with patients. $J$ Nutr 133:556S-562S, 2003

${ }^{2}$ American Diabetes Association: Executive summary: standards of medical 
care in diabetes-2009. Diabetes Care 32:S6S12, 2009

${ }^{3}$ Bantle JP, Wylie-Rosett J, Albright A, Apovian CM, Clark NG, Franz MJ, Hoogwerf BJ, Lichtenstein AH, Mayer-Davis E, Mooradian AD, Wheeler ML: Nutrition recommendations and interventions for diabetes: a position statement of the American Diabetes Association. Diabetes Care 31 (Suppl. 1):S61-S78, 2008

${ }^{4}$ U.S. Department of Health and Human Services: Final MNT regulations. CMS1169-FC. Federal Register, 1 November 2001. 42 CFR Parts 405, 410, 411, 414, and 415

${ }^{5}$ American Dietetic Association: Comparison of the American Dietetic Association (ADA) Nutrition Care Process for nutrition education services and the ADA Nutrition Care Process for medical nutrition therapy (MNT) services [article online] Available from www.eatright.org/advocacy/ mnt. Accessed 6 November 2009

${ }^{6}$ Lacey K, Pritchett E: Nutrition care process and model: ADA adopts road map to quality care and outcomes management. $J$ Am Diet Assoc 103:1061-1072, 2003

${ }^{7}$ Daly A, Michael P, Johnson EQ, Harrington CC, Patrick S, Bender T: Diabetes White Paper: Defining the delivery of nutrition services in Medicare medical nutrition therapy vs Medicare diabetes selfmanagement training programs. $J$ Am Diet Assoc 109:528-539, 2009

${ }^{8}$ Camelon KM, Hadell K, Jamsen PT, Ketonen KJ, Kohtamaki HM, Makimatilla S, Törmälä ML, Valve RH: The Plate Model: a visual method of teaching meal planning. $J$ Am Diet Assoc 98:1155-1158, 1998

${ }^{9}$ Diabetes Care and Education Dietetic Practice Group: American Dietetic Association Guide to Diabetes Medical Nutrition Therapy and Education. Ross TA, Boucher JL, O'Connell BS, Eds. Chicago, American Dietetic Association, 2005

${ }^{10}$ Diabetes 1 and 2 Evidence Analysis Project: American Dietetic Association Evidence Analysis Library Web site. Available from https://www.adaevidencelibrary. com/topic.cfm?cat $=1615$. Accessed 6 November 2009

"Pastors JG, Warshaw H, Daly A, Franz M, Kulkarni K: The evidence of medical nutrition therapy in diabetes management. Diabetes Care 25:608-613, 2002

${ }^{12}$ UKPDS Study Group: Response of fasting plasma glucose to diet therapy in newly presenting type II diabetic patients. Metabolism 39:905-912, 1990

${ }^{13}$ Franz MJ, Monk A, Barry B, McClain K, Weaver T, Cooper N, Upham P, Bergenstal R, Mazze RS: Effectiveness of medical nutrition therapy provided by dietitians in the management of non-insulindependent diabetes mellitus: a randomized, controlled clinical trial. J Am Diet Assoc 95:1009-1017, 1995

${ }^{14}$ Kulkarni K, Castle G, Gregory R, Holmes A, Leontos C, Powers M, Snetselaar L, Splett P, Wylie-Rosett J: Nutrition practice guidelines for type 1 diabetes mellitus posi- tively affect dietitian practices and patient outcomes. J Am Diet Assoc 98:62-70, 1998

${ }^{15}$ Glasgow RE, Toobert DJ, Hampson SE, Brown JE, Lewinsohn PM, Donnelly J: Improving self-care among older patients with type II diabetes: the "sixty-something ..." study. Patient Educ Couns 19:61-74, 1992

${ }^{16}$ Sadur CN, Moline N, Costa M, Michalik D, Mendlowitz D, Roller S, Watson R, Swain BE, Selby JV, Javorski WC: Diabetes management in a Health Maintenance Organization. Diabetes Care 22:2011-2017, 1999

${ }^{17}$ Delahanty LM, Halford BH: The role of diet behaviors in achieving improved glycemic control in intensively treated patients in the Diabetes Control and Complications Trial. Diabetes Care 16:1453-1458, 1993

${ }^{18}$ DCCT Research Group: Expanded role of the dietitian in the Diabetes Control and Complications Trial: implications for practice. J Am Diet Assoc 93:758-767, 1993

${ }^{19}$ Franz M, Callahan T, Castle G: Changing roles: educators and clinicians. Clinical Diabetes 12:53-54, 1994

${ }^{20}$ Johnson EQ, Valera S: Medical nutrition therapy in non-insulin-dependent diabetes mellitus improves clinical outcomes. J Am Diet Assoc 95:700-701, 1995

${ }^{21}$ Johnson EQ, Thomas M: Medical nutrition therapy by registered dietitians improves HbAlc levels (Abstract). Diabetes 50 (Suppl. 2):A21, 2001

${ }^{22}$ Christensen NK, Steiner J, Whalen J, Pfister R: Contribution of medical nutrition therapy and diabetes self-management education to diabetes control as assessed by hemoglobin Alc. Diabetes Spectrum 13:72-75, 2000

${ }^{23}$ Brown SA: Studies of educational interventions and outcomes in diabetic adults: a meta-analysis revisited. Patient Educ Couns 16:189-215, 1990

${ }^{24}$ Brown SA, Upchurch S, Anding R, Winter M, Ramirez G: Promoting weight loss in type II diabetes. Diabetes Care 19:613-624, 1996

${ }^{25}$ Padgett D, Mumford E, Hynes M, Carter R: Meta-analysis of the effects of educational and psychosocial interventions on management of diabetes mellitus. J Clin Epidemiol 41:1007-1030, 1988

${ }^{26}$ Norris SL, Engelgau MM, Venkat Narayan KM: Effectiveness of self-management training in type 2 diabetes. Diabetes Care 24:561-587, 2001

${ }^{27}$ Knowler WC, Barrett-Connor E, Fowler SE, Hamman RF, Lachin JM, Walker EA, Nathan DM; the Diabetes Prevention Program Research Group: Reduction in the incidence of type 2 diabetes with lifestyle intervention or metformin. $N$ Engl J Med 346:393-403, 2002

${ }^{28}$ Wadden TA, West DS, Neiberg RH, Wing RR, Ryan DH, Johnson KC, Foreyt JP, Hill JO, Trence DL, Vitolins MZ; the Look AHEAD Research Group: One-year weight losses in the Look AHEAD study: factors associated with success. Obesity 17:713-722, 2009

${ }^{29}$ DCCT Research Group: The effect of intensive treatment of diabetes on the development and progression of long-term complications in insulin-dependent diabetes mellitus. N Engl J Med 329:977-986, 1993

${ }^{30}$ Mayer-Davis EJ, Bell, RA, Dabelea D, D'Agostino R, Imperatore G, Lawrence JM, Liu L, Marcovina S; The SEARCH for Diabetes in Youth Study Group: The many faces of diabetes in American youth: type 1 and type 2 diabetes in five race and ethnic populations. Diabetes Care 32:S99-S101, 2009

${ }^{31}$ Fagot-Campagna A, Venkat Narayan KM, Imperatore G: Type 2 diabetes in children [Editorial]. BMJ 322:377-378, 2001

${ }^{32}$ U.S. Department of Health and Human Services Centers for Medicare \& Medicaid Services: Medicare eligibility tool [online]. Available from http://www.medicare.gov/ MedicareEligibility/. Accessed 6 November 2009

${ }^{33}$ National Conference of State Legislatures: State laws mandating diabetes health coverage [article online]. Available from http://www.ncsl.org/programs/health/ diabetes.htm. Accessed 20 September 2009

${ }^{34}$ Centers for Medicare and Medicaid Services Medicare Learning Network: MLN matters, No. SE0660 [publication online]. Available from http://www.cms.hhs.gov/ MLNMattersArticles/downloads/SE0660. pdf. Accessed 6 November 2009

${ }^{35}$ DPP Research Group: Costs associated with the primary prevention of type 2 diabetes mellitus in the Diabetes Prevention Program. Diabetes Care 26:36-47, 2003

${ }^{36}$ American Dietetic Association: Referrals to MNT . . . as easy as 1-2-3 [article online]. Available from http://www.eatright. org/ada/files/0109_Referrals_1-2-3-_MNT_ Flyer2.pdf. Accessed 6 November 2009

${ }^{37}$ National Certification Board for Diabetes Educators: 2009 Certification Handbook for Diabetes Educators [publication online]. Arlington Heights, Ill., National Certification Board for Diabetes Educators, 2009. Available from http://www.ncbde.org/ documents/HB2009Final.pdf. Accessed 6 November 2009

Sara F. Morris, MAT, MPH, RD, is a research assistant in the Department of Nutrition at the University of North Carolina in Chapel Hill. Judith WylieRosett, EdD, RD, is a professor and head of the Division of Behavioral and Nutritional Research in the Department of Epidemiology and Population Health at the Albert Einstein College of Medicine in Bronx, N.Y. 